\title{
First description of the female of Xerophaeus espoir Platnick, 1981 (Aranei: Gnaphosidae)
}

\author{
Первоописание самки Xerophaeus espoir Platnick, 1981 \\ (Aranei: Gnaphosidae)
}

\author{
Yuri M. Marusik \\ Ю.М. Марусик
}

Institute for Biological Problems of the North RAS, Portovaya Str. 18, Magadan Russia;
Zoological Museum, University of Turku, FIN-20500 Turku Finland
ИБПС ДВО РАН, Портовая 18, Магадан 685000. E-mail: yurmar@mail.ru

KEY WORDS: Aranei, spiders, Gnaphosidae, first description, redescription.

КЛЮЧЕВЫЕ СЛОВА: Aranei, пауки, Gnaphosidae, первоописание, переописание.

ABSTRACT. Female of Xerophaeus espoir Platnick, 1981 from Seychelles Islands is described for the first time and male is redescribed. The species was found on Marianne and North islands for the first time.

РЕЗЮМЕ. Впервые описана самка Xerophaeus espoir Platnick, 1981 с Сейшельских о-вов, переописан самец. Вид впервые отмечен на островах Mariannе и North.

\section{Introduction}

A gnaphosid spider Xerophaeus espoir was described from the male holotype from Mahe Island, Seychelles. It is still known by the single taxonomic entry (cf. Platnick, 2008), although it was twicely reported by M.I. Saaristo from Cousine and Cousin [Saaristo, 1999; Saaristo \& Hill, 2002].

Study of new and older material revealed on one hand more localities for this species: Marianne and North, and on the other hand the record from Cousin was found to be based on a misidentification.

New material also contained the previously unknown female of $X$. espoir. One subadult female with developed epigyne was found on North, and a mature female with a kind of mating plug was collected on Marianne Island. The main goal of this paper is the illustration and description of the famale, redescription of the male and brief discussion of the position of $X$. espoir.

Specimens were photographed using an Olympus SZX12 stereomicroscope and Olympus Camedia C5050 camera. The images have been mounted using "CombineZM" image stacking software. Photographs were taken in dishes of different size with paraffin in the bottom. Different sized holes were made in the bottom to keep the specimens in the correct position. All measurements are given in millimeters.
Xerophaeus espoir Platnick, 1981

X.e. Platnick, 1981: 454, f. 5-6 (D $\left.{ }^{7}\right)$.

X.e.: Saaristo \& Hill, 2002: 224.

MATERIAL EXAMINED. SEYCHELLES: Cousine, 1 ○', Jan. 1998, O. Bourquin leg. (MZT AA 0.398); Marianne, $1+$, 23.03.2002, J. Gerlach leg. (MZT AA 2.278); Mahé, Bon Espoir, 300 m., holotype $\sigma^{7}, 21.06$. 1972, P.L.G. Benoit and J.J. Van Mol leg. (MRAC 143.231); North, 1 \%, 30.07.2000, J. Gerlach leg., (MZT AA 1.321)

DESCRIPTION. The male has been well described by Platnick [1981]. Habitus, eye pattern and male palp are shown on Figs 2, 4-7.

Female. Total length: 7.2. Carapace: 3.6 long, 2.45 wide. AME largest, 0.21 . Chelicera as in male with 3 outer teeth, and one inner denticle. Legs spination different from male, and variable within one specimen. Femur I besides 3 dorsal spines, may have 2 prolateral spines, or 2 prolateral and one retrolateral spines. Habitus and eye pattern of female are shown on Figs 1 and 3. Epigyne as in Figs 8-10, with two apical pockets, not joined, posterior edge of pocket extended into long ridge.

DISTRIBUTION. This endemic species has been collected from Cousin [Saaristo \& Hill, 2002]; Cousine [Saaristo, 1999], Marianne (new record), Mahe [Platnick, 1981] and North (new record).

COMMENTS. When the species was described it was difficult to place it precisely because of the lack of a revision of Afrotropical Gnaphosidae. A newly published survey of the Gnaphosidae genera of the world [Murphy, 2007] contains excellent figures of the generotype of Xerophaeus capensis Purcell, 1907. Comparison of our specimens and figures provided by Murphy [2007: 386-387] revealed similarities in chelicera indentation, shape and size of retrolateral tibial apophysis and presence of dorsal abdominal scutum in male. Eyes, epigyne and bulbus are quite different in $X$. 

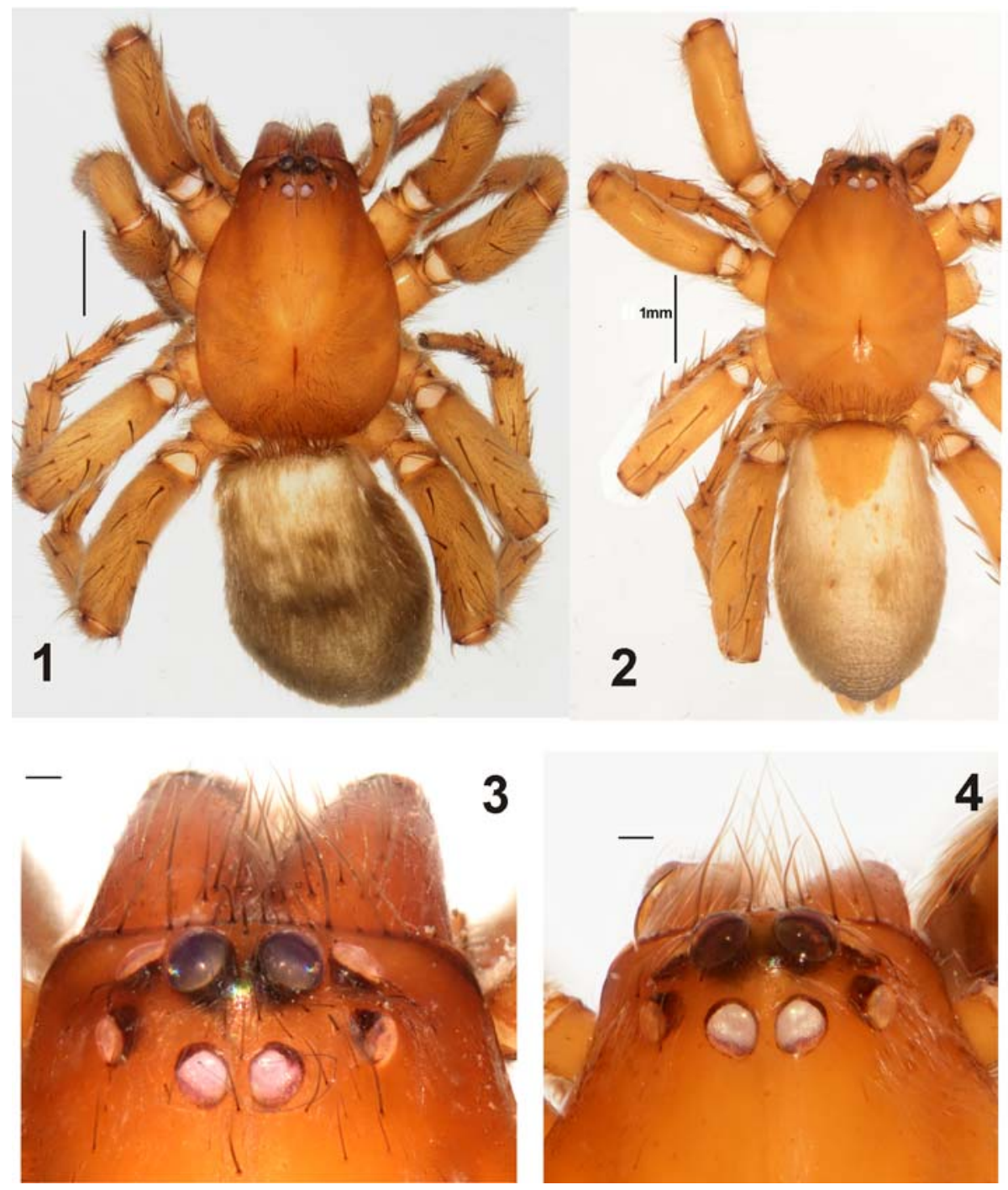

Figs 1-4. Habitus and ocular area of Xerophaeus espoir. 1-2 - female and male, dorsal; 3-4 - ocular area of female and male, dorsal. Scale $1-2=1 \mathrm{~mm}, 3-4=0.1 \mathrm{~mm}$.

Рис. 1-4. Габитус и глазное поле Xerophaeus espoir. 1-2 - самка и самец, сверху; 3-4 - глазное поле самки и самца, сверху. Масштаб: $1-2=1$ мм, 3-4 = 0,1 мм.

espoir and $X$. capensis. The generotype has subequal eye sizes, while in Seychellian species anterior median eyes are larger than others. Epigyne in generotype has only one apical pocket and large kidney-shaped receptacula, while in $X$. espoir there are two unfused pockets, long lateral ridges, small round receptacula, long insemination duct with large accessorial glands. It is very likely that $X$. espoir is not congeneric with $X$. capensis and should be placed in another genus. But judgments about $X$. espoir position can be made only after revision of African Gnaphosidae.

ACKNOWLEDGEMENTS. I wish to thank Seppo Koponen who allowed study of material stored in Zoological Museum University of Turku and use of equipment in the museum. English of the final draft was kindly checked by Justin Gerlach.

\section{References}

Murphy J. 2007. Gnaphosid genera of the world. St Neots, Cambs: British Arachnological Society. Vol.1. P. i-xii, 1-92; Vol.2. P. i-11, 93-605.

Platnick N.I. 1981. Contributions à l'étude de la faune terrestre des îles granitiques de l'archipel des Séchelles (Mission P.L.G. Benoit - J.J. Van Mol 1972), Araneae: Gnaphosidae // Revue Zool. afr. T.95. P.451-457.

Platnick N.I. 2009. The world spider catalog, version 10.0. American Museum of Natural History, online at http://research.amnh. org/entomology/spiders/catalog/index.html

Saaristo M.I. 1999. An arachnological excursion to the granitic Seychelles, 1-26th January, 1999. Arachnid species lists for Silhouette, Cousine \& Mahé // Phelsuma. Vol.7. Suppl.A. P.1-12.

Saaristo M.I., Hill M.J. 2002. Spiders (Arachnida, Araneae) collected by BirdLife GEF Island Assessment Project 1999-2000 // Hill M.J. (ed.). Biodiversity Surveys and Conservation Potential of Inner Seychelles Islands. Atoll Research Bulletin. P.221-253. 


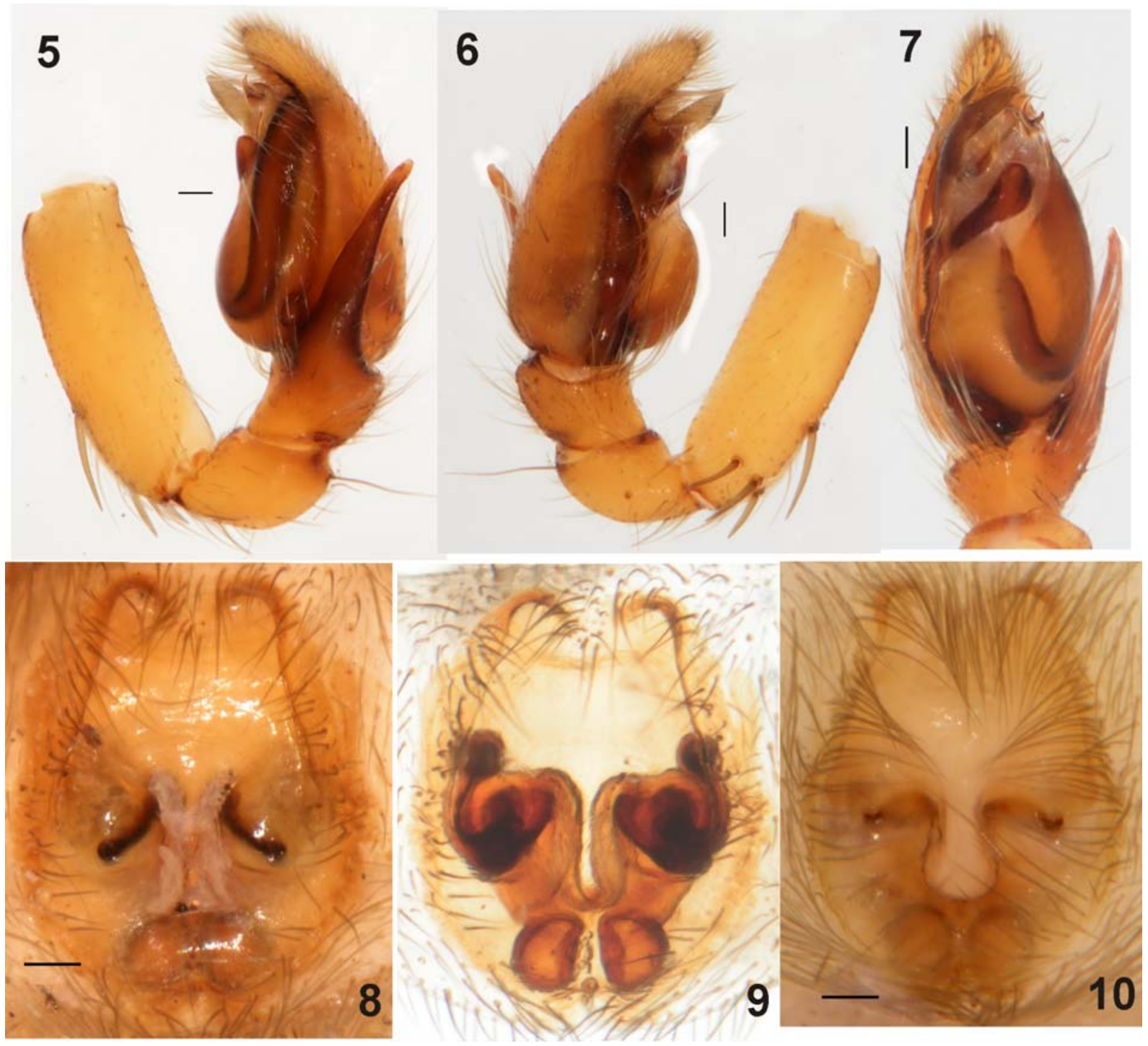

Figs 5-10. Copulatory organs of Xerophaeus espoir. 5-7 - male palp, retrolateral, prolateral and ventral, respectively; 8, $10-$ epigyne, ventral; 9 - epigyne, dorsal. $10-$ subadult female with developed epigyne. Scale $=0.1 \mathrm{~mm}$.

Рис. 5-10. Копулятивные органы Xerophaeus espoir. 5-7 - пальпа самца, ретролатерально, пролатерально и вентрально, соответственно; 8, 10 - эпигина, вентрально; 9 - эпигина, дорсально; $10-$ субадультная самка. Масштаб $=0,1 \mathrm{мм.}$ 